\title{
Digital devotees: Vernacular authority in a new kind of religious movement ${ }^{1}$
}

\author{
Robert Glenn Howard, University of Wisconsin, Madison, U.S.A.
}

Back in October of 1994, I was just starting out as a graduate student in Los Angeles studying contemporary religious narrative. Not wanting to spend the money on cable television from my tiny student budget, I often explored the rich variety of broadcast television still available in Los Angeles at that time. Late one night, I was flipping through fuzzy channels when I came across the very sharp broadcast of what seemed to be some sort of television news show.

On a generic looking newsroom set, an older-than-usual female and male team of hosts sat in front of a blue background with a stylized map of the world on the wall above their heads. During this show, Rexella (the female host) described a news item from the previous week. Often, clippings from the Wall Street Journal or the New York Times would appear on the screen. After she briefly introduced the news story, she turned to Jack (the male host) and asked what the story could mean. Dramatically raising his hands and with an animated speaking style more appropriate for the revival tent than for TV, Jack placed the news into the context of biblical prophecy. With a barrage of bible quotes, every news item imaginable from a rare "white buffalo" born in the Midwestern United States to the most recent exploits of the Russian president - all indicated that the "End Times" were on the verge of beginning. After a little research, I discovered that the show was Jack Van Impe Presents, and that Jack and his wife Rexella had been predicting that Jesus Christ would return to earth very soon since at least 1953.

While Jack Van Impe Presents did appear on the Christian network Trinity Broadcasting for 23 years, Jack Van Impe Ministries also purchased airtime in hour segments offered for "infomercials" on regular broadcast networks around the English speaking world and beyond. In order to fund its airtime as well as other ministries, the show would offer religious items in exchange for donations at the end of each broadcast. In 1994, several weeks of the show offered a VHS copy of the small budget Christian movie Years of the Beast. The movie presented a dramatic narrative of the final days before Christ's final return at the end of time.

\footnotetext{
${ }^{1}$ This paper was presented at the conference of the International Society for Ethnology and Folklore (SIEF), Lisbon, April 2011.
} 


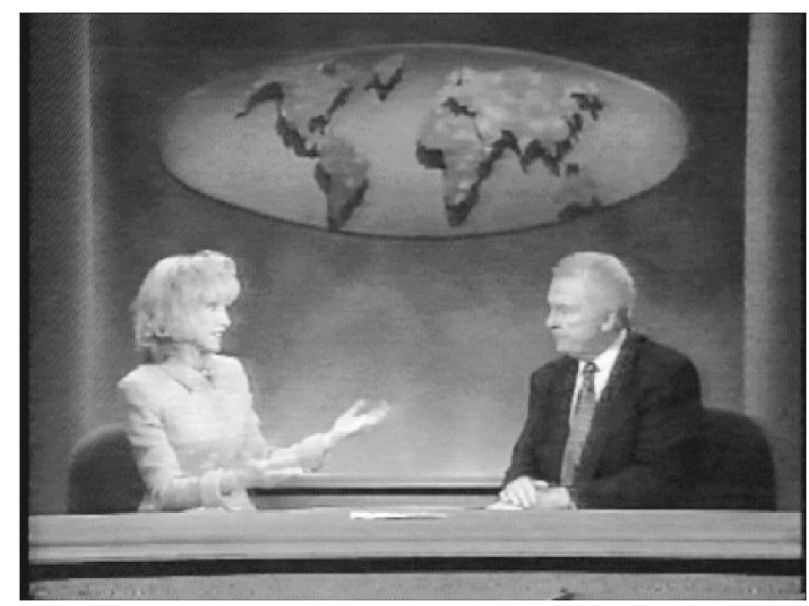

Jack Van Impe Presents, October 1994

Since I was interested how religious narratives portrayed in mass media might be functioning in the everyday lives of believers, I decided to try to find people who had watched Years of the Beast, or even find people who were interested in Jack Van Impe Presents and show them the movie to see what they thought about it. So I began to talk to friends, family, and even to local churches and ministries. To my surprise, everyone I talked to responded to Jack Van Impe's End Times ministry much as I did: with interest, but no experience. A few, actually, responded with hostility to Jack Van Impe. None would be suitable for my small study. Frustrated by my inability to find people to interview about the show, I decided to post a message to a common kind of Internet forum at that time: UseNet newsgroups. In the Fall 1994, I posted the following message to five different news groups that were topically defined by their focus on broadly Christian issues:

I am writing a paper for a college class on Jack Van Impe and his film Years of the Beast, has anyone seen it? Please write me with your comments and views on the second coming. Thanks! (Howard 1994)

Within days, I had received hundreds of responses and was corresponding regularly with fifty people. Somewhat unwittingly, I was swept up into a hidden community of Christians who were using the Internet to share information about the End Times. I was fascinated with the combination of technological savvy and intense faith. I asked my respondents: "Who is the authority on this?" I was told to look at the books and shows of media evangelists including Jack Van Impe and Hal Lindsey - but with the significant caveat that no human can rightly know God's divine plan (Howard 1997).

Although evangelists like Van Impe, Lindsey, and Tim LaHaye, have exerted a large influence in this group, they claim to offer no institutionally authoritative interpretations. As Hal Lindsey famously put it, "I am attempting to step aside and let the prophets speak" (Lindsey and Carlson 1970, p. 6). On UseNet, these regular 
believers seemed to reject all authority as they deliberated about the minute details of a complex narrative interpretation of biblical prophecy that they all seemed perfectly confident was about to begin. Back in 1994, it seemed to me that this was a new form of church where nobody was in charge: an online place where everyday people could simply sidestep the reified doctrines of protestant institutions and the commercially driven influence of wealthy evangelical ministries by harnessing this new medium to their own ends.

However, after 15 years working with, studying, and writing about this group of online believers, it became clear that I was quite wrong in my initial assessment. Instead of nobody being in charge in this community, everybody is in charge. Freed from institutions, a kind of digitally empowered vernacular authority has been quietly exerting itself since the dawn of the Internet age.

In this article, I describe vernacular authority as the basis of a new religious movement I have termed "vernacular Christian fundamentalism" (Howard 2011). Not just a new religious movement, vernacular Christian fundamentalism is also as a new kind of religious movement - "new" because even as these individuals have grown more connected online, no new central leadership has emerged. Instead, the movement takes shape as its believers engage in a kind of ritualized deliberation that they say generates a new kind of church that exists only on the Internet - what they call a "virtual ekklesia."

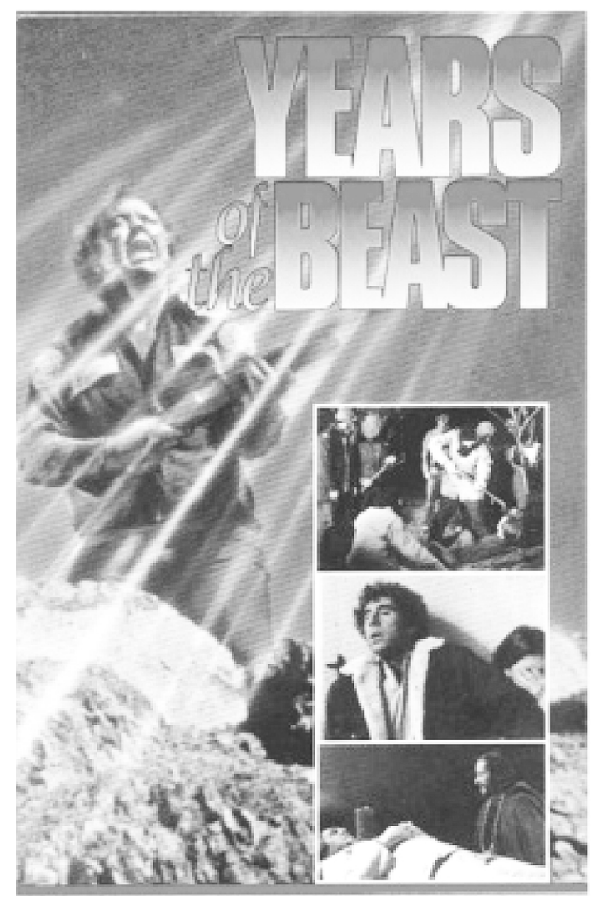

Years of the Beast, October 1994 


\section{Ritual deliberation in a virtual ekklesia}

The ritual deliberation that enacts this church first started occurring in private email lists and "newsgroups" as early as 1981. In the late 1990s, it appeared on amateur Web sites like that of a retired business woman who predicted that the Rapture - the moment when true believers will be bodily removed from the earth just before the end of time - would occur in 1998; and then she predicted it again in 1999, and 2000, and 2001.

And on the site of a computer engineer and his wife who decided to put their amateur Bible studies online because: "We find a life and fellowship on the Internet $[\ldots]$ Who would have thought? [... that] the [Holy] Spirit is able to pierce through beyond mere characters floating on a screen" (Cheryl and Ernie 1999); and on sites like The Watcher that focused on demon-built monuments on Mars and government conspiracy. This young couple in Montana told me how they act in a way much like "first-century Christians" online. Rejecting the need for religious institutions, they said: "it's absolutely viable for the 'church,' if you understand what I mean by that: the ekklesia; to meet on the Internet" (Jane and John 1999).

Today, Internet technologies have evolved from those early email-based forums, through the period of static web pages during the 1990s, to today's more dynamic participatory media. These media allow individuals to easily exchange personal content in a wide variety of forms: establishing networks of friends on Facebook, sharing digital photos on sites like Flickr, or video on sites like YouTube. Participatory media allow individuals to co-produce content, to create webs of interconnected personal expression. In fact, this co-production is the lifeblood of the online movement. There is no physical church, institutional leadership, or single website that defines it. Instead, the aggregate volition of its members flows through these webs of human expression giving life to the shared imaginary of its participants as they enact their church together in ritual deliberation.

Despite this diffuse nature, the movement can be located by recognizing when its four definitive beliefs are emergent in online deliberation. Those beliefs are: 1) in biblical literalism, 2) in the experience of spiritual rebirth, 3) in the need to evangelize, and 4) in the End Times interpretation of biblical prophecy. When topics that take these ideas as given become the focus of an online discussion, the participants both recognize and enact their church. In discussions of when the Rapture will occur, who will be the Antichrist, what form the Mark of the Beast might take, or the role of demons in daily life, vernacular Christian fundamentalism emerges - bottom up - from webs of shared expression.

Scholars have long recognized that communities using traditional ritualized action (like home blessings or ground-breaking ceremonies) can assimilate a specific geographic location into the symbolic space imagined by a community. When Mircea Eliade famously articulated his conception of "ritual construction" $(1959$, p. 52), he certainly wasn't looking forward to the purely discursive spaces 
of network communication. Still, his idea points us toward the fundamentally ritual function of deliberating about the End Times online.

Religious studies scholar Catherine Bell has suggested that rituals exhibit the basic characteristics of "public assembly, the repetition of gestures already considered 'ritual tradition' by a community, and the invocation of divine beings" (1997, p. 166). Even if we treat online locations as real-world places, online ritual deliberation is not any normal sort of ceremonial "public assembly." More central to all ritual, however, is that individuals must "do something in such a way that the doing itself gives the acts a special or privileged status" (Bell 1997, p. 166). Ritual deliberation enjoys precisely this elevated position of "privileged status" because it has no hope of actually ending. It seeks not conclusion, but, instead, repetitious action. Elevating an everyday activity through repetition is, in fact, a hallmark of ritual.

As ritual theorist Jonathan Smith describes it:

Ritual is a means of performing the way things ought to be in conscious tension to the way things are. Ritual relies for its power on the fact that it is concerned with quite ordinary activities placed within an extraordinary setting, that what it describes and displays is, in principle, possible for every occurrence of these acts. But it also relies for its power on the perceived fact that, in actuality, such possibilities cannot be realized. (Smith 1987, p. 109)

Smith develops his idea from the work of Claude Lévi-Strauss. Lévi-Strauss describes the power of ritual as emerging from the repetition of "infinite distinctions." While making distinctions is an ordinary behavior in deliberation and elsewhere, ritual distinction ascribes "discriminatory values to the slightest shade of difference. It has no concern for the general, but on the contrary goes into detail about the varieties and sub-varieties in all the taxonomic categories" (1981, p. 672). Ritual deliberation proceeds in precisely this fashion. It enables individuals to continually locate the minute details of biblical writings in everyday news events. However, it seeks no "general" conclusion. Instead, it ritually constructs the movement's virtual space through its repeated expression.

\section{The diverse forms of vernacular End Times media}

Ritual deliberation can be found in all forms of participatory media. On the personal profile page of the popular social networking tool MySpace, for example, a sixty-one-year-old man in Fort Collins, Colorado, named Paul posted his belief that recent "sex scandals in the church" may indicate the approach of the End Times. One of Paul's friends on MySpace, a thirty-six-year-old man in Arkansas named Kenneth, described Christ's near return as an event that "could knock your socks off" (Kenneth 2007). Or on his friend Rhonda's page where Kenneth posted the comment: "The end times are near ... come quickly Lord Jesus!!!!" 


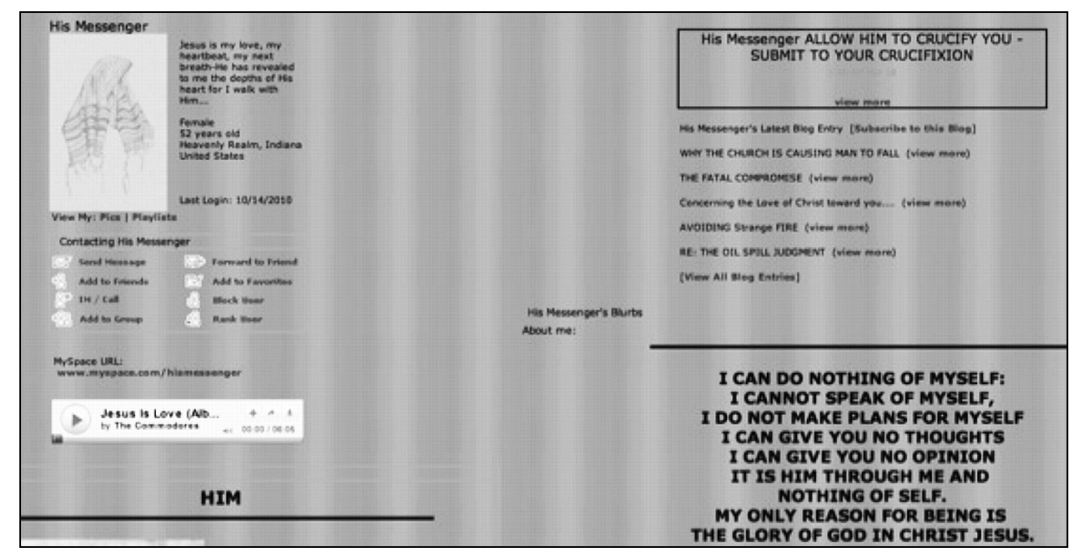

“His Messenger” MySpace page, 2006

Like others in the movement, Rhonda (or "His Messenger" as she often identified herself) sees her online activities functioning much "as it was in the beginning - [in the] Book of Acts." A forty-nine-year-old grandmother in Indiana, Rhonda enters trances that allow her to act as God's agent. She transmits messages from God that are often about what she calls "the end time battle." As the end of time approaches, demons increasingly begin to act in our world, and Rhonda feels she must facilitate God's actions against these evil spirits that she calls "principalities" by "warring" against them through trance, prayer, and prophecy (Rhonda 2008; Howard 2009). In one case, Rhonda posted on her MySpace page about a magazine cover she had recently seen: "One of today's news headlines read, 'Rapper Kanye West Poses as Jesus." "Then she recounted how the Holy Spirit whispered the word "poser" in her ear as she thought about the 2006 cover of the magazine Rolling Stone. Realizing the heretical nature of portraying oneself as Christ, God directed her to pray for Kanye West. Entering a trance (indicated by all caps) she posted: "I DECREE IT UNTO YOU, KANYE, AS THE LORD HAS GIVEN ME UTTERENCE HERE ON YOUR BEHALF ... BE IT UNTO YOU AS HE HAS SPOKEN IN JESUS' MATCHLESS NAME!" (Rhonda 2006). After this invocation, she implores him to repent for being a poser.

Another of Rhonda's friends on MySpace - a twenty-eight-year old man in Missouri named James - uses a posting service to share video and audio files of his prophetic trances and then links them to his profile page. In one of these videos, he performed a blessing over several U.S. states by speaking in the voice of God dressed in a bright red University of Nebraska Corn Huskers watch cap and football jersey. Another video blogger engaged in prophetic interpretation instead of trance. Karl posted seventeen messages - one over an hour long - that have been forwarded, linked to, and re-posted by users to at least seven different video hosting forums.

One video, entitled "End Times: Antichrist and False Prophet," began with Karl seated on what appeared to be a folding aluminum lawn chair. He was facing the 
camera and spoke directly to it. At his left was what appeared to be the speaker of a home stereo system with an American flag draped over it. On top of that rested Karl's well-worn Bible. Karl began this video post much as he did all his posts: in measured and comforting tones. He stated, "Most of us have heard the term 'End Times' used before. And in truth, we are living in the End Times right now." He went on to assert that anyone who "doesn't have God and His Son in their life will be enslaved or killed during the soon coming times" (Karl 2007).

Other participants in vernacular Christian fundamentalism use online software like WordPress or Blogger to create websites containing reverse dated posts we usually think of as blog entries. Britt Gillette, for example maintains a blog titled: "A Christian Examination of Bible Prophecy and Emerging Technology ..." Britt searches the Internet for information about technologies that he feels demonstrate that the "Tribulation Period" will occur within his lifetime. The Tribulation is a period of wars (including the persecution of Christians by putting them in concentration camps, etc.) that will begin just before the end of time (Gillette 2008).

Todd, another blogger, copied one of Britt's posts about the Mark of the Beast and pasted it as a featured article on his own blog: Rapture Ready (Gillette 2007a; Gillette 2007b). Reading Britt's post at Rapture Ready, another blogger named Job copied the post and pasted it into his own blog, Jesus Christology (Job 2008a).

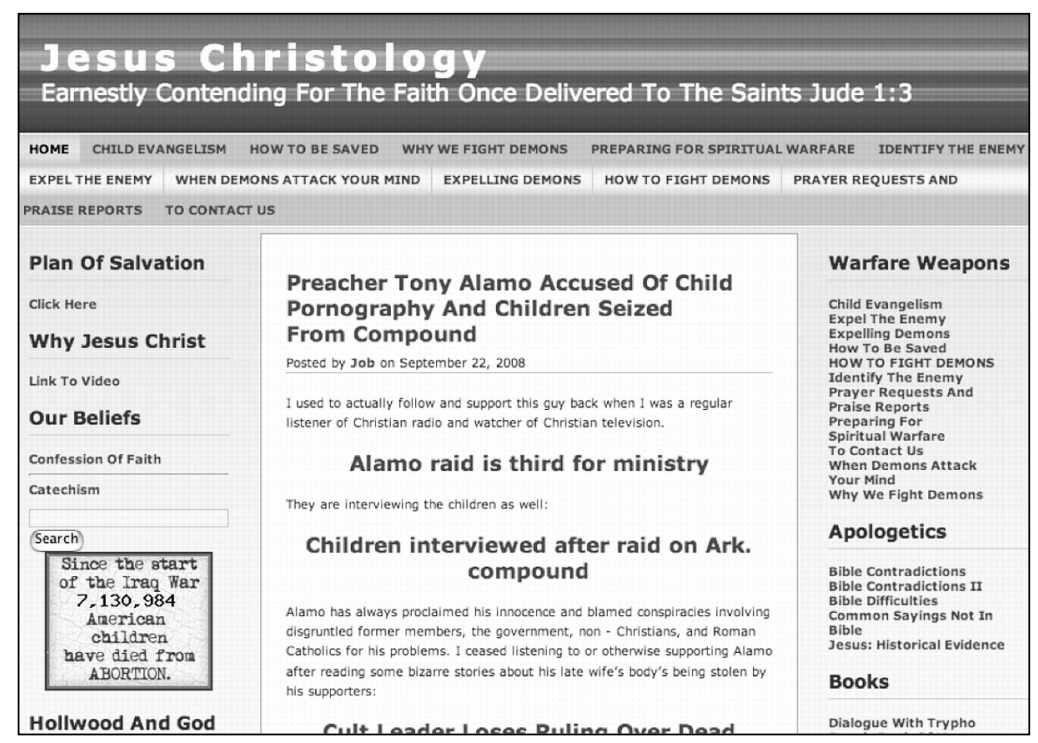

Jesus Christology, 2008

There, Job described how (during the Tribulation period) fellow believers will witness God "pouring out his wrath upon and scattering the church." In the comments section of his blog, a group of regulars engage in public ritual deliberation. 
During the 2008 US presidential campaign, Job asked about Barack Obama: "Does Anyone Know the Number of Barack HUSSEIN Obama's Name?" A commenter posted the following response:

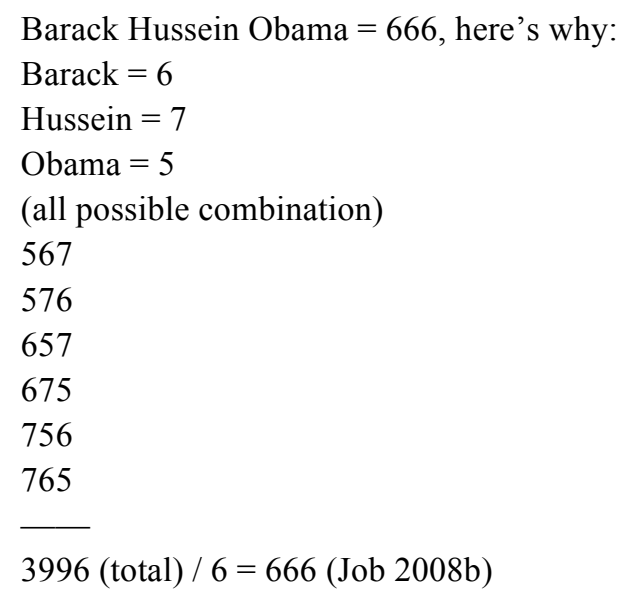

Among these various forms of co-produced participatory media, ritual deliberation occurs most commonly in topically-specific moderated forums. Some of these forums are quite large. BibleForums.org, for example, has over 20,000 members and over 1.3 million posts. On a forum site of this size, sub-forums are formed around specific topics. Here, the "End Times Chat" group allows individuals to engage in ritual deliberation about the End Times - and it is always filled to capacity, holding 4,000 posts at any given time (BibleForums.org 2008).

Smaller forums offer believers network locations that are more specifically tailored to them. These forums offer the best conditions for ritual deliberation. RaptureAlert.com, for example, was created by a forty-four-year-old retired police officer named Michael (Mickey 2008a).

A typical exchange occurring on the forum is from February 15, 2008, entitled "A Rumbling in the Middle East." First, Michael invited his audience of regulars to engage in deliberation writing: "Just another earthquake here in the last days or a harbinger of things to come? Only the Lord knows but I'll bet the air in and around Israel could practically be cut with a knife right now." Individuals responded immediately. A user identified as "jo anna" wrote:

WOW! I hadn't heard about this one yet. I heard about the 2 in Greece yesterday, but not this one. I've also been reading how lake Mead is drying up and then with the problems Georgia and Florida are having and the HUGE push about global warming! And of course all that's going on war wise in the middle east. My heart is racing at how close we could be to going home! I am so ready to be with Jesus and done with this place! Oh how I pray people accept Christ quickly before it's too late! (Mickey 2008b) 


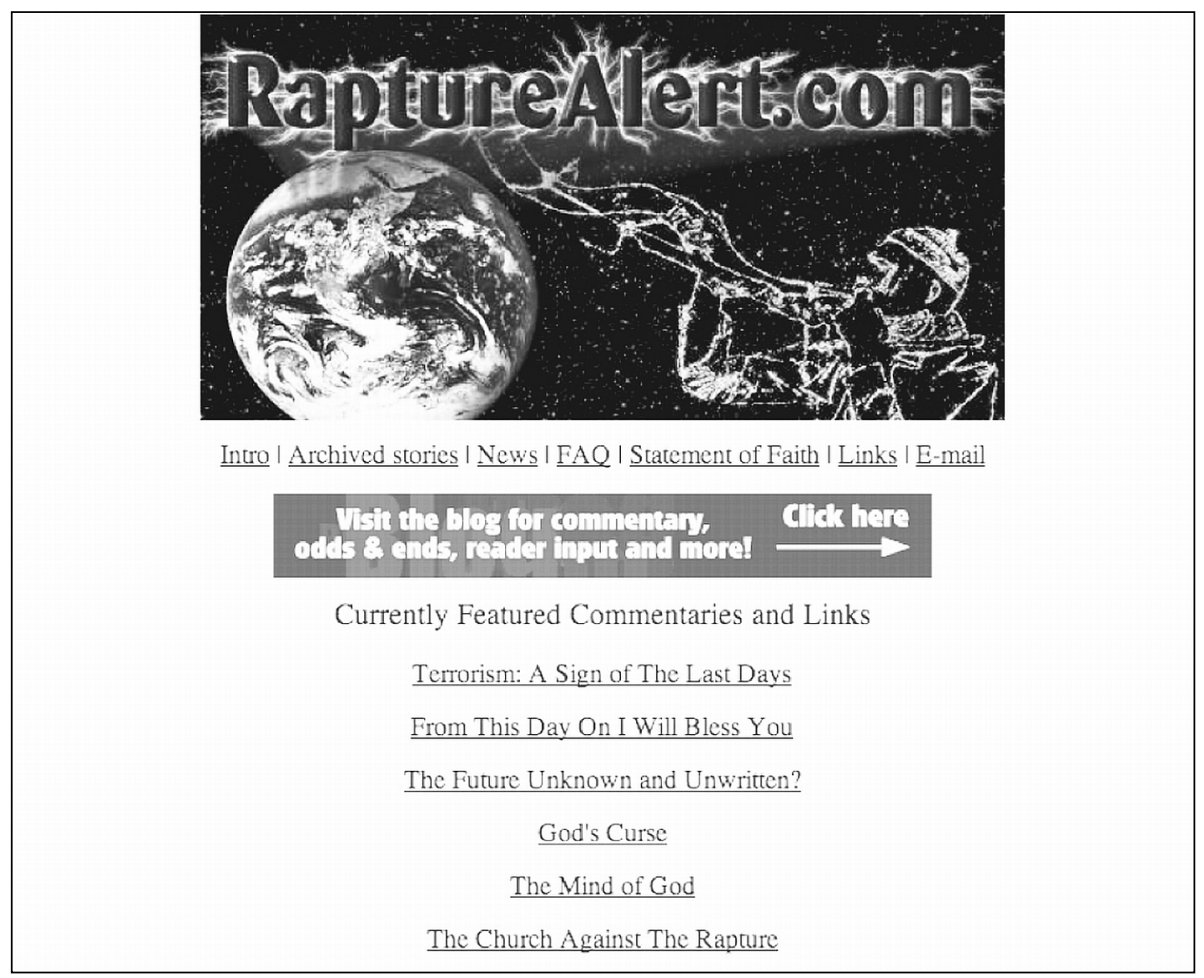

RaptureAlert.com, 2008

With the deliberation started, Michael responded by writing: "Amen, Jo Anna! A lot is going on and on a variety of fronts. Broadening the spectrum a bit, do you realize we have had FOUR campus shootings in the United States in one short week?" Then, ten different people in fourteen more posts considered nine different world events reported by various news organizations as other indicators that the beginning of the Tribulation Period was near at hand. The deliberation climaxed as one commenter wrote in all capital letters: "I AM SO LOOKING FORWARD TO A FRONT ROW SEAT TO THE MAJOR BUTT KICKING SATAN IS GOING TO GET SOON!" (Mickey 2008b)

\section{Vernacular authority of the social divine}

In this ritual deliberation, individuals enact vernacular Christian fundamentalism. This sort of religiosity is a form of "lived religion" (see McGuire 2008), but it is also specifically vernacular. By "vernacular" I mean it is not just lived, but is lived by individuals who create their church alongside but apart from any specific religious institutions (Howard 2008a and 2008b). As they imagine their "church on the Internet" (their virtual ekklesia), they imagine it not as defined by a place, a 
sect, a leader, or an organization, but instead as enacted when individuals identify themselves as in agreement with the four defining beliefs of the movement. Typically, this identification is not overtly stated but is instead implicit in the ability to participate in ritualized deliberation about key features of the End Times prophetic narrative. While these individuals perceive themselves to have a common identity, there is no geography or institution that makes the links between them explicit. Instead, it is only when they exchange words online that their common identity is enacted. Each act of communication itself is an individual choice; each is the product of individual volition. However, with repetition over time, those choices accumulate to enact a larger shared volition. This aggregate volition is the vernacular authority that renders their common identity as members of this leaderless virtual ekklesia perceptible both to each other and to outsiders.

Today's media offer individuals more opportunities to construct their own personalized systems of belief than ever before in history, and this raises important questions. What roles do communication technologies play in these individualistic constructions of religious belief? What dangers are emerging in the heavily mediated and individually constructed religious marketplaces of the digital age? (Ammerman 1997; Cimino and Lattin 1998; Roof 1999).

It seems that the central motive behind these individuals' ritual deliberation is a fundamentally human one. As the scholar of communication James W. Carey famously noted, individuals engage in communication not just to transmit knowledge but also as a means for "the construction and maintenance of an ordered, meaningful cultural world" (1989, pp. 18-19). People do not want to do this alone. They seek to construct their worlds in connection with others. To realize this connection, they seek to share their understanding of that world. Through online ritual deliberation about the End Times, these digital devotees aggregate their volition to generate something new in human history: an Internet-based and leaderless new religious movement.

\section{References}

Ammermann, Nancy T. (1997): Organized religion in a voluntaristic society. Sociology of Religion 58, pp. 203-215.

Bell, Catherine (1997): Ritual: Perspectives and Dimensions. New York: Oxford University Press.

Bibleforums.org. 2008. Welcome to the BibleForums Christian Message Board and Forums. BibleForums Christian Message Board and Forums, http://bibleforums.org/forum/ (accessed 1 February 2008).

Carey, James W. (1989): Communication as Culture: Essays on Media and Society. New York: Routledge.

Cheryl and Ernie (1999). RE: basic questions. July 21, 1999. Email to Robert Howard. Cimino, Richard; Don Lattin (1998): Shopping for Faith: American Religion in the New Millennium. New York: John Wiley \& Sons. 
Gillette, Britt (2007a): 666: The Mystery of Revelation. In: Rapture Ready, http://www.raptureready.com/featured/gillette/666.html (accessed 8 November 2007).

Gillette, Britt (2007b): 666: The Mystery of Revelation. In: Brittgillette.com, http://brittgillette.com/WordPress/?p=41 (accessed 8 July 2007).

Gillette, Britt (2008): The Holy Spirit. In: Brittgillette.com, http://brittgillette.com/WordPress/ (accessed 4 February 2008).

Eliade, Mircea (1959) [1957]: The Sacred and the Profane: The Nature of Religion. Transl. Willard R. Trask. New York: Harcourt Brace and Company.

Howard, Robert Glenn [IZZY9MR@mvs.oac.ucla.edu] (1994). On-line posting. YEARS of the BEAST. 30 October 1994. <news: bit.listserv.christia>.

Howard, Robert Glenn (1997): Apocalypse in your in-box: End Times communication on the Internet. Western Folklore. 56, pp. 295-315.

Howard, Robert Glenn (2008a): Electronic hybridity: the persistent processes of the Vernacular Web. Journal of American Folklore 121 (Spring 2008), pp. 192-218.

Howard, Robert Glenn (2008b): The Vernacular Web of participatory media. Critical Studies in Media Communication 25 (December), pp. 490-512.

Howard, Robert Glenn (2009): Crusading on the Vernacular Web: the folk beliefs and practices of online spiritual warfare. In: Trevor J. Blank, ed.: Folklore and the Internet: Vernacular Expression in a Digital World. Logan, Utah: Utah State University Press, pp. 126-141.

Howard, Robert Glenn (2011): Digital Jesus: The Making of a New Christian Fundamentalist Community on the Internet. New York: New York University Press. Jane and John (1999): Personal interview, 17 October 1999.

Job (2008a): A brief list of reasons why Christians should not support Barack HUSSEIN Obama. In: Jesus Christology Earnestly Contending For The Faith Once Delivered To The Saints Jude 1:3, http://healtheland.wordpress.com/category/anti-christ/ (accessed 14 February 2008).

Job (2008b): Does anyone know the number of Barack HUSSEIN Obama's name? http://healtheland.wordpress.com/2008/01/26/does-anyone-know-the-number-ofbarack-hussein-obamas-name/\#comments (accessed 26 January 2008).

Karl (2007): End Times: Antichrist and False Prophet. In: Veoh, http://www.veoh.com/videos/v301990TPdBNhza (accessed 1 February 2008).

Kenneth (2007): A question for you ... In: MySpace, http://blog.myspace.com/index.cfm?fuseaction=blog.view \& friendID $=164752885 \&$ blog $\mathrm{ID}=252794507 \&$ Mytoken=44AE7F76-7311-448B-98581E077DC988E719675468 (accessed 13 April 2007).

Leví-Strauss, Claude (1981) [1971]: The Naked Man. Transl. John and Doreen Weightman. New York: Harper \& Row.

Lindsey, Hal; C. C. Carlson (1970): The Late Great Planet Earth. Toronto \& New York: Bantam Books.

McGuire, Meredith B. (2008): Lived Religion: Faith and Practice in Everyday Life. New York, Oxford University Press.

Mickey, Michael (2008a): The Blog. In: RaptureAlert.com: The Blog, http://rapturealert.blogspot.com/ (accessed 1 February 2008). 
Mickey, Michael (2008b): The Middle East: back to the brink. In: RaptureAlert.com: The Blog, http://rapturealert.blogspot.com/2008/02/middle-east-back-to-brink.html (accessed 14 February 2008).

Rhonda (2006): Passion of the Kanye? In: BlogMySpace, http://blog.myspace.com/index.cfm?fuseaction=blog.listAll\&friendID $=54504106 \&$ start $\mathrm{ID}=88191732 \&$ StartPostedDate $=2006-02-$ 15\%2015:55:00.0\&next $=1$ \&page $=23 \&$ Mytoken $=279 F 8$ A46-D20E-461CAD43E34CBB48718E17150783 (accessed 24 January 2006).

Rhonda (2008): RE: ???. Email to Robert Howard (9 March 2008).

Roof, Wade Clark (1999): Spiritual Marketplace: Baby Boomers and the Remaking of American Religion. Princeton: Princeton University Press.

Smith, Jonathan Z. (1987): To Take Place: Toward Theory in Ritual. Chicago: University of Chicago Press. 